\title{
THE URGENCY OF THE PUBLIC POLICY OF THE CONSTRUCTION SERVICE COOPERATIVES IN REALIZING THE WELFARE OF THE COMMUNITY BASED ON JUSTICE VALUE
}

\author{
Anis Mashdurohatun ${ }^{1}$, Kurnia Halomoan ${ }^{2}$, Gunarto $^{3}$ \\ ${ }^{1}$ Faculty of Law, Sultan Agung Islamic University, Semarang, Indonesia. anism@ unissula.ac.id
}

\begin{abstract}
Cooperatives are the support of the national economic order which is an integral and inseparable part, so that's why it is not only the mandate of the constitution but also becomes hopes in building the people's economy. This study utilized a sociological juridical approach by examining the rules, concepts, community views, legal doctrines obtained from secondary legal materials, as well as applicable laws and regulations relating to the issues discussed. The results found the factors that influence cooperative public policy that has not been able to play a role in the field of government construction services by basing on legal system theory are caused by 3 legal subsystem factors (first legal factors, second legal structure factors, and legal culture factors). Thus, based on the values of justice, it is necessary to reconstruct the laws and regulations, especially the provisions of Article 6, Article 15 and Article 16 of Law No. 25 of 1992 concerning cooperatives.
\end{abstract}

Keywords: Construction Services Cooperative; Justice;

Article Received: 18 October 2020, Revised: 3 November 2020, Accepted: 24 December 2020

\section{Introduction}

Cooperatives are part of the economic order, which means that in their activities, cooperatives take part in achieving a prosperous economic life, both for those who are members of the association itself and for the surrounding community. The cooperative as an association for joint welfare conducts business and activities in the field of meeting the common needs of its members ${ }^{1}$. Cooperatives have a significant role in developing joint ventures of people who have limited economic capacity. In the context of efforts to advance the position of the people who have limited economic capacity, the Government of Indonesia pays attention to the growth and development of Cooperative associations (Suharto, 2005 ).

Cooperatives are the support of the national economic order as an integral and inseparable part ${ }^{2}$, so cooperatives are not only a constitutional mandate but are also a hope in building the people's

\footnotetext{
${ }^{1}$ Camelia Fanny Sitepu, Hasyim, Perkembangan Ekonomi Koperasi di Indonesia, Jurnal Niagawan, Vol 7 No 2 July 2018, pp.59-68
}

economy, even the father of Indonesian Cooperative, Moh. Hatta extremely stated that cooperatives are the only apparatuses for production. Article 33 Paragraph (2) of the 1945 Constitution states that building businesses in Indonesia other than cooperatives are State-Owned Enterprises (BUMN/D) and Private-Owned Enterprises (BUMS), but the spirit of making cooperatives a pillar of the national economy is an ideal that must be realized. Along with changes in the global economic order, it also has an impact on the paradigm and challenges of coping in Indonesia. The Indonesian government considers that Law No. 25 of 1992 is no longer in accordance with the legal needs and development of cooperatives. After several long seminars and debates, Law No. 25 of 1992, which has been in effect for more than twenty-five years, has been renewed with Law No.17 of 2012. Law No.17 of 2012 was made with a view to adjusting the global

2 Mubyarto, Ekonomi Pancasila, Gagasan dan Kemungkinannya. PT. Pustaka LP3ES Indonesia. Jakarta, 2007, page. $39-42$ 
economic conditions that are moving fast and increasingly dynamically, so that cooperatives can carry out adjustment and penetration of the economy in global markets, it is not difficult and impossible. ${ }^{3}$

Theoretically, the source of strength is the cooperatives as business entities in the context of economic life. The savings that can be a source of cooperative strength are not limited to their economic value. That power can also be sourced from non-economic factors which have an indirect influence on the economic activities of community members and cooperative business entities. The benefits of this cooperative are always related to economic and social benefits. Because cooperatives in addition to providing economic benefits also have attention and concern for social aspects such as education, social environment, the environment, and others. In this case, the cooperative has another strength because the cooperative can provide the possibility of introducing new technology through savings by getting information that is direct and available to every member who needs it. All of that is seen in the framework of the role of the cooperative autonomously for each member who has decided to become a member of the cooperative. Thus, as long as the cooperative can produce benefits for its members, it will encourage people to cooperate because it is considered beneficial.

Talking about the ability of the people to control or oversee the course of the economy, means talking about in whose hands sovereignty is in the hands of the state or in the hands of the people. According to the constitution, sovereignty should be in the hands of the people. But because the reality that we have encountered tends to be different from the

3 Aji Basuki Rohmat, Analisis Penerapan PrinsipPrinsip Koperasi Dalam Undang-Undang Koperasi (Study of Law No. 25 Tahun 1992 and Law No.17 Tahun 2012), Jurnal Pembaharuan Hukum, Volume II No. 1 January - April 2015, pp.138-147. mandate of the constitution, so it is really needed to realize a socially equitable economy in Indonesia today which is to return the sovereignty of the people. Without the growth of people sovereignty, the Indonesian economy is unfair (Baswir, 1997 ). Ironically, nowadays, the construction service sector is growing rapidly, this business is dominated by individuals and companies that lead to the capitalist concept. Business entities in the field of construction, range from individuals, Trading Business (UD), CV, Limited Liability Company (PT), and Cooperative business entities. The construction services sector absorbs a large number of workers, both professional and nonskilled. In the field of construction services, there is no visible cooperative business entity that competes professionally. The government structure in training is quite complete, the Ministry of Cooperatives, the Department of Cooperatives in the Province and Regency / City and the Ministry of State-Owned Enterprises.

Profound transformations in the global economic context, often called the globalization of the economy, have had a major impact on cooperatives. Some feared a degeneration of cooperatives. They feared that these profound transformations in the market would lead cooperatives to relinquish their identity and degenerate into typical capitalist institutions. ${ }^{4}$

Based on the description it is interesting to study in-depth the factors that influence cooperative public policies that have not been able to play a role in the field of government construction services and how the ideal construction of cooperative public policy in the field of construction services in realizing public welfare based on the values of justice.

${ }^{4}$ Caroline Gijselinckx Patrick Develtere, The Cooperative Trilemma. Co-operatives between market, state and civil society, Paper presented at the 8th Conference of the European Sociological Association on 'Conflict, Citizenship and Civil Society', sessions of the Economic Sociology Research Network, Glasgow, 3-7 september 2007 pp.1. 


\section{Research Method}

This study uses a sociological juridical approach by examining the rules, concepts, community views, and legal doctrines obtained from secondary legal materials, as well as applicable laws and regulations relating to the issues discussed in order to realize the function of the Act Cooperative No. 25 of 1992, the role of the community as an agent of change is very important (Murdiana, 2015). ${ }^{5}$ The specifications of this study are descriptive under the problem and purpose of the study. This study describes a number of variables relating to the problem under study (Hanim, 2014). ${ }^{6}$

\section{Research Results and Discussion}

Business entities that are under the economic democratic system or the populist economic system adopted by the Indonesian state consist of three forms of business entities, namely State-Owned Enterprises (BUMN), Private-Owned Enterprises (BUMS), and Cooperatives.

\section{A. State-Owned Enterprises (BUMN)}

State-Owned Enterprises (SOE/BUMN) are business entities established by the government with state / state-owned capital. In addition to serving the public interest, SOEs are also a source of state revenue. There are three forms of BUMN, namely Public Company, State-owned Company, and Bureau Company.

State-Owned Enterprises (SOE/BUMN), whose capital is derived in whole or in part from separated state assets, is one of the economic actors in the national economic system, in addition to private businesses and cooperatives. BUMN is a concrete manifestation of article 33 of the 1945 Constitution (UUD 1945), which has a strategic position for improving people's welfare. In order for the government to run well, the state established SOEs

5 Elfa Murdiana, Analisis Yuridis Sosiologis Terhadap Perubahan Undang-Undang Koperasi, e-journal STAIN Jurai Siwo Metro, pp.1-13

${ }^{6}$ Lathifah Hanim, Perlindungan Hukum Bagi Para Pihak Dalam E-Commerce Sebagai Akibat Dari Globalisasi to exploit the natural wealth for the prosperity of the people. As economic actors, SOEs must be the main concern in advancing the Indonesian economy and realizing an Indonesia that is more prosperous and able to play a role in global economic competition. In its development, SOEs, especially BUMN company faces the risk of loss that leads to bankruptcy when the management is done unprofessionally, not based on the principles of efficiency and not applying the principles of good corporate governance ${ }^{7}$

\section{B. Private-Owned Enterprises (BUMS)}

Private-Owned Enterprise (BUMS) is a business entity established by a private party with fully private capital, both individuals and the cooperation of several people. Private sector business activities are engaged, among them engaged in the extractive industries, agriculture, trade, and services. Private companies in running their business can be in the form of Limited Liability Companies (PT), Joint Partnerships (CV), Firma $(\mathrm{Fa})$, and individual companies. Examples of private-owned business entities, namely PT ASTRA International, PT Panasonic, PT Indofood, and PT Maspion.

Private-owned Business Entity is a business entity whose owner is entirely in the hands of an individual or private party. Private-owned Business Entity is a business entity whose owner is entirely in the hands of an individual or private party. This business entity is intended for profit, but there are also private companies which are not looking for profit but more social motives, such as hospitals, schools, academies, universities, orphanages, and others. The form of a private business entity can be divided into several types, namely Individual Companies, Partnerships, and Limited Companies.

Ekonomi, Jurnal Pembaharuan Hukum, Vol.I No. 2 MayAugust 2014, pp.191-199.

${ }^{7}$ I Made Asu Dana Yoga Arta, Status Kepemilikan Badan Usaha Milik Negara (Bumn) Persero Setelah Dikuasai Oleh Pihak Swasta, Jurnal IUS, Vol.V No.2 August 2017, pp.178-188 


\section{Cooperative}

According to Law No. 25 of 1992, cooperatives are business entities consisting of individuals or legal entities of cooperatives by basing their activities based on cooperative principles as well as a populist economic movement based on family principles. Following Article 33 of the 1945 Constitution, the business entity that best suits the soul and personality of the Indonesian nation is cooperatives. Cooperatives were established to improve the welfare of members in particular and the community in general and to build the national economic order in order to create a developed, just, and prosperous society. Examples of cooperative business entities, namely Savings and Loans Cooperatives (Kosipa), Multipurpose Cooperatives (KSU), School Cooperatives, Student Cooperatives (Kopma), and Village Unit Cooperatives (KUD).

Cooperative is a business entity whose members are members of several cooperatives or legal entities that have the same interests to reduce costs and obtain economic strength through joint ownership. Each owner is a member who pays an annual fee and gets a share of each profit or service. Because the cooperative is a legal entity which is a tax object because in the cooperative there is the Remaining Operations (SHU) which is taxable income. In Indonesia, cooperatives are regulated by Law No. 25 of 1992, namely the Law on cooperatives. Cooperatives aim to prosper members in particular and improve the national economy in general, from that goal, it will be seen from the annual financial statements made by cooperatives. Cooperatives have the main characteristics that distinguish them from other business entities, namely the existence of a dual identity (the dual identity of the member) in its members. Members of the cooperative act as owners and at the same time users of cooperative services (user own oriented firm) (Warno, 2012). ${ }^{8}$
The economic policies pursued by the government during the reform era were oriented towards the recovery of the nation's economic conditions after the monetary crisis. Many state companies were originally given monopoly rights in carrying out business activities related to important production branches for the state and concerning the livelihoods of the people during the old and new order. Then their monopoly rights were revoked for various reasons, ranging from inefficient and ineffective the performance of State-Owned Enterprises (SOEs) to the reasons for the demands of globalization that want freedom and openness in unlimited global investment. The basic problem that becomes a demand for the government is how to maintain the stability of the nation's economy through the use of natural resources and human resources to the maximum but by still being able to guarantee the protection of natural assets and guarantee protection for the livelihoods of many people.

One of the strategies to improve the welfare of the nation is carried out by the government by implementing the SOE demonopolization policy. SOEs, which were originally granted monopoly rights through the Law for conducting business activities of a public character, are subsequently released of monopoly rights also through the issuance of the latest Law. Especially for PT. PLN (Persero) is an example of a State Company which was originally given the right to monopoly through Law No. 15 of 1985 concerning electricity. Subsequently, this monopoly right was revoked by enacting Law No.30 of 2009 concerning electricity. The interesting thing then is the return of monopoly rights in the business of providing electricity to PT. PLN (Persero) through the decision of the Constitutional Court No.111/ PUU-XIII/ 2015.

8 Warno, Kepatuhan Koperasi Dikota Semarang Dalam Membuat Laporan Promosi Ekonomi, Journal of STIE Semarang, Vol.4 No.2 June 2012, pp.29-38. 
Table 1: The Organizer of Construction Business Activities in the Directorate General of Highways in the Ministry of Public Works and Public Housing (PUPR) 2019;

\begin{tabular}{|c|c|c|c|c|c|c|c|c|c|}
\hline \multirow[t]{2}{*}{ No } & \multirow[t]{2}{*}{$\begin{array}{l}\text { Name Of } \\
\text { Office/Province }\end{array}$} & \multirow[t]{2}{*}{$\begin{array}{l}\text { Center Of Construction } \\
\text { Service Activities }\end{array}$} & \multirow{2}{*}{$\begin{array}{c}\text { Total } \\
\text { Contra } \\
c t \\
\text { Amoun } \\
t\end{array}$} & \multirow{2}{*}{$\begin{array}{l}\text { Number Of } \\
\text { Contract } \\
\text { Packages }\end{array}$} & \multicolumn{2}{|c|}{ Business Entity } & \multirow{2}{*}{$\begin{array}{l}\text { The } \\
\text { Num } \\
\text { ber } \\
\text { Of } \\
\text { Expe } \\
\text { rts }\end{array}$} & \multicolumn{2}{|c|}{$\begin{array}{c}\text { Connoisseurs Of } \\
\text { Profits }\end{array}$} \\
\hline & & & & & $\begin{array}{l}P T / \\
C V\end{array}$ & $\begin{array}{c}\text { Cooper } \\
\text { ative } \\
\text { Busine } \\
\text { ss } \\
\text { Enterp } \\
\text { rise }\end{array}$ & & $\begin{array}{c}P T / C \\
V\end{array}$ & $\begin{array}{c}\text { Coopera } \\
\text { tive } \\
\text { Busines } \\
s \\
\text { Enterpri } \\
\text { se }\end{array}$ \\
\hline 1. & Aceh & Road and Bridge Construction & 41 & $762,101,085,000$ & 41 & - & 1,025 & 205 & - \\
\hline 2. & Medan & Road and Bridge Construction & 60 & $2,828,413,744,430$ & 60 & - & 1,500 & 300 & - \\
\hline 3. & Padang & Road and Bridge Construction & 41 & $1,180,315,155,600$ & 41 & - & 1,025 & 205 & - \\
\hline 4. & Jambi & Road and Bridge Construction & 39 & $1,062,159,133,711$ & 39 & - & 975 & 195 & - \\
\hline 5. & Palembang & Road and Bridge Construction & 29 & $536,936,172,000$ & 29 & - & 1,025 & 145 & - \\
\hline 6. & Jakarta & Road and Bridge Construction & 42 & $2,086,243,553,565$ & 42 & - & 1,025 & 210 & - \\
\hline 7. & Semarang & Road and Bridge Construction & 37 & $2,146,589,187,662$ & 37 & - & 925 & 185 & - \\
\hline 8. & Surabaya & Road and Bridge Construction & 57 & $2,302,509,925,050$ & 57 & - & 1,425 & 285 & - \\
\hline 9. & Mataram & Road and Bridge Construction & 15 & $342,916,764,417$ & 15 & - & 395 & 75 & - \\
\hline 10. & Kupang & Road and Bridge Construction & 63 & $1,102,725,883,000$ & 63 & - & 1,575 & 315 & - \\
\hline 11. & Banjarmasin & Road and Bridge Construction & 51 & $1,646,447,393,000$ & 51 & - & 1,275 & 255 & - \\
\hline 12. & Balikpapan & Road and Bridge Construction & 72 & $2,755,785,609,000$ & 72 & - & 1,800 & 360 & - \\
\hline 13. & Makasar & Road and Bridge Construction & 35 & $968,519,262,950$ & 35 & - & 875 & 175 & - \\
\hline 14. & Palu & Road and Bridge Construction & 31 & $899,757,367,684$ & 31 & - & 775 & 155 & - \\
\hline 15. & Menado & Road and Bridge Construction & 38 & $1,275,630,610,470$ & 38 & - & 950 & 190 & - \\
\hline 16. & Ambon & Road and Bridge Construction & 35 & $806,099,889,286$ & 35 & - & 875 & 175 & - \\
\hline 17. & Manokwari & Road and Bridge Construction & 55 & $1,316,970,866,000$ & 55 & - & 1,375 & 275 & - \\
\hline 18. & Jayapura & Road and Bridge Construction & 71 & $2,222,499,953,800$ & 71 & - & 1,735 & 355 & - \\
\hline 19. & Lampung & Road and Bridge Construction & 15 & $1,001,278,401,202$ & 15 & - & 375 & 75 & - \\
\hline 20. & Pontianak & Road and Bridge Construction & 35 & $1,416,414,361,000$ & 35 & - & 875 & 175 & - \\
\hline 21. & Kendari & Road and Bridge Construction & 22 & $361,996,196,215$ & 22 & - & 550 & 110 & - \\
\hline 22. & Merauke & Road and Bridge Construction & 27 & $739,954,629,000$ & 27 & - & 675 & 135 & - \\
\hline
\end{tabular}

Note $*)$. The number of calculations from the survey average

Based on the data above, $19.76 \%$ of profits and welfare are only enjoyed by certain individuals who have capital, ability and opportunity. This characterizes one of the capitalist economies.

The description of construction service implementation activities for the last 5 (five) years from 2015 to 2019 within the Ministry of Public Works and Public Housing, Construction Business Entity Activities in this data shows that cooperative business entities have never been involved in this contract.

Table 2: The Cooperative Business Entity is not involved in the organization of construction services within the Directorate General of Highways in the Ministry of Public Works and Public Housing (PUPR) Fiscal Year 2015 to 2019;

\begin{tabular}{|c|c|c|c|c|c|c|c|c|}
\hline \multirow[t]{2}{*}{ No } & \multirow{2}{*}{$\begin{array}{l}\text { Fiscal } \\
\text { Year }\end{array}$} & \multirow[b]{2}{*}{$\begin{array}{l}\text { Budget } \\
\text { implementation } \\
\text { list The } \\
\text { Ministry of } \\
\text { Public Works } \\
\text { and Public } \\
\text { Housing } \\
\text { (PUPR) In } \\
\text { Trillion }\end{array}$} & \multirow{2}{*}{$\begin{array}{l}\text { Center Of } \\
\text { Construction } \\
\text { Service Activities }\end{array}$} & \multicolumn{4}{|c|}{ Director General of Highways } & \multirow[t]{2}{*}{ Note } \\
\hline & & & & $\begin{array}{l}\text { Number } \\
\text { Of } \\
\text { Contract } \\
\text { Packages }\end{array}$ & $\begin{array}{l}\text { Total } \\
\text { Contract } \\
\text { Amount }\end{array}$ & $\mathrm{PT} / \mathrm{CV}$ & $\begin{array}{l}\text { Coope } \\
\text { rative } \\
\text { Busine } \\
\text { ss } \\
\text { Enterp } \\
\text { rise }\end{array}$ & \\
\hline 1. & 2019 & 108.703 & $\begin{array}{l}\text { Road and Bridge } \\
\text { Construction }\end{array}$ & 911 & 29,762 & 911 & - & \multirow{5}{*}{$\begin{array}{l}\text { Overview the } \\
\text { number of } \\
\text { contract } \\
\text { activities in } \\
\text { Director } \\
\text { General of } \\
\text { Highways }\end{array}$} \\
\hline 2. & 2018 & 107.386 & $\begin{array}{l}\text { Road and Bridge } \\
\text { Construction }\end{array}$ & 900 & 29.401 & 900 & - & \\
\hline 3. & 2017 & 106.229 & $\begin{array}{l}\text { Road and Bridge } \\
\text { Construction }\end{array}$ & 982 & 29.085 & 982 & - & \\
\hline 4. & 2016 & 98.192 & $\begin{array}{l}\text { Road and Bridge } \\
\text { Construction }\end{array}$ & 822 & 26.884 & 822 & - & \\
\hline 5. & 2015 & 114.834 & $\begin{array}{l}\text { Road and Bridge } \\
\text { Construction }\end{array}$ & 962 & 31.441 & 962 & - & \\
\hline
\end{tabular}

Source: Konreg Ministry of Public Works and Public Housing 2020 
The Government should also continue to encourage cooperatives to play a role in infrastructure development. Examples of Cooperative Business Entities that have played a role in the infrastructure sector are the Semen Gresik Citizens Cooperative which has contributed to providing construction material for several national construction companies. This is realized if the coaching is done in earnest. Cooperative business entities need to play an even greater role in supporting the growth of financial services with professional management. Examples of Savings and Loans Cooperatives (KSP) or Savings and Loans Units (USP) as of July 5, 2017 are 10.7 million people with a business capital of Rp 57.8 trillion. One of the national secondary cooperatives, Kopelindo Infrastruktur has played a role as a provider of construction materials for several national construction companies.

In the economic system, State-Owned Enterprises (BUMN) play several roles, namely as producers of goods and/or services needed in order to realize the greatest prosperity of the people, as public services, to balance large private forces, and to help to develop small businesses or cooperative. BUMN is also a significant source of state revenue in the form of various types of taxes, dividends and privatization proceeds. The benchmark of SOE's success can be seen from how big its role is in contributing to national development. In reality, although SOEs have achieved their initial goals as agents of development and are the driving force behind the creation of corporations, these goals are achieved at a relatively high cost. The performance of BUMNs is considered unsatisfactory and there is still a bureaucracy that causes professionalism to be low. SOEs are deemed not to have the readiness to compete in global business competition, so their productivity and efficiency need to be improved. ${ }^{9}$

9 Josefhin Mareta, Constitutional Economic Principles in the Privatization of State Owned Enterprises:
The Cooperative Business Entity in the Construction Services Sector in the SOE would be able to enter all business sectors so as to be able to contribute optimally in development. Cooperatives in a broader economic level, so far cooperatives are only saving and borrowing and distribution, even though it's like a success story in Europe, cooperatives can go into all business sectors. The role of cooperatives in the direction of national development is to realize cooperatives as drivers of competitive and sustainable development. The effort was carried out through increasing the contribution of cooperative exports in national exports, increasing the participation of cooperatives in national infrastructure development, increasing the role of cooperatives in financial services, developing national tourism, global production chains, and enhancing cooperative synergies with Village-Owned Enterprises (BUM Desa).

In an effort to create a harmonious and orderly community life, in the social life a legal system is needed. The system is a unit consisting of elements or elements that interact with one another. In the system, it does not want a conflict between the elements that exist in the system, if there is a conflict it will be resolved immediately by the system. So the basic understanding contained in the system is:

a. The system is goal oriented .

b. The whole is more than the sum of the parts.

c. A system is oriented to a larger system, namely its environment.

d. The operation of the parts of the system creates something valuable.

e. Each part must match each other.

Constitutional Journal, Volume 15, Number 1, March 2018, pp.118-139. 
f. There is a unifying force that binds the system (control mechanism). ${ }^{10}$

Thus, law as a system means that the law is a unified whole consisting of parts or elements that are closely related to each other. In other words, the legal system is a unit consisting of elements that have interactions with one another and work together to achieve the objectives of that unit. ${ }^{11}$ So essentially the system, including the legal system, is an intrinsic unity and is divided into sections, in which every problem or problem finds an answer or a solution. The answer is in the system itself. ${ }^{12}$ So the legal system has four functions, as stated by Lawrence M. Friedman, namely:

a. Law as part of the social control system (social control) that regulates human behavior;

b. As a means to resolve disputes (dispute settlement);

c. The legal system has a function as a social engineering function, and

d. Law as social maintenance, which is a function that emphasizes the role of law as maintaining the status quo that does not want change (Friedman, 1984 ). ${ }^{13}$

Thus the factors that influence cooperative public policy that have not been able to play a role in the field of government construction services by basing on legal system theory are caused by 3 legal subsystem factors (first legal factors, second legal structure factors and legal culture factors).

Legal factors, namely Law Number 25 of 1992 about Cooperatives have not explicitly governed the form and type of cooperatives in the field of construction services. The structural factor is that there is no government alignments regarding the regulation of construction services and the

${ }^{10}$ Satjipto Rahardjo, , Legal Studies, sixth printing, Citra Aditya Bakti, Bandung, 2006, page.48

${ }^{11}$ Sudikno Mertokusumo, Know the Law: An Introduction, Fourth printing, Liberty, Yogyakarta, 2008, page. 122 .

${ }^{12}$ Satjipto Rahardjo, Op Cit, page. 123. profitability of business entities does not favor workers / employees. Business entities outside the cooperative business entity have not been able to assist the government in realizing the welfare of the community. Furthermore, in terms of legal culture, the capital of government construction services still relies on outsiders, namely investors, and covers the economic system of capitalism.

The main key in the welfare state is the issue of guaranteeing people's welfare by the state. Regarding this matter, Jurgen Habermas argues that guaranteeing the welfare of all the people is central to the modern state. Furthermore, according to Habermas, the guarantee of the welfare of all the people in question is manifested in the protection of, "The risk of unemployment, accident, ilness, old age, and death of the breadwinner must be covered largely through welfare provisions of the state". ${ }^{14}$.

Contribution of thoughts originating from Muslim scientists in perfecting the concept of Welfare state is an idea put forward by Anwarul Yaqin and Faruq An Nabahan. According to them Welfare State is the responsibility of the state in the welfare of individuals and society, including increasing spiritual values and meeting basic needs. In addition, the state uses the rule of law to organize education, protect the health of the weak (women, children, elderly people), eradicate economic exploitation, social services, including monitoring the main factors driving the economy, stopping muamalah from being prohibited and fixing prices if needed (Djauhari,2008). ${ }^{15}$

In a welfare state, according to Sentanoe Kertonegoro, both risk groups must get attention to

${ }^{13}$ Lawrence M.Friedman, American Law, WW Norton \& Company, New York, 1984, page.5-6.

${ }^{14}$ Gianfranco Poggi, The Development of the Modern State "Sosiological Introduction, Standford University Press, California, 1992, page, 126.

15 Djauhari, Politik Hukum Negara kesejahteraan Indonesia, Unissula Press,Disertasi,Semarang, 2008, page.72 
overcome. The reason is that the fundamental risk is collective macro-nature and is felt by the whole or the majority of the community as well as economic risk. While specific risks are risks that are more to the individual macro, so the impact is felt by individuals or business units. ${ }^{16}$

Based on economic development and social development there are four forms of the welfare state:

a. A prosperous country, namely a country that has high economic development and high social development. Countries that apply this principle are Scandinavian and Western European countries that apply universal and corporate welfare models.

b. Benevolent countries, namely countries that have relatively low economic development, but they still make social investment.

c. Cheapskate countries, namely countries that have high economic development, but low social development. Examples of countries that fall into this category are Japan and the United States.

d. Weak countries, namely countries with low economic development and social development. Indonesia, Cambodia, Laos and Vietnam are included in this category (Suharto, 2005). ${ }^{17}$

Pancasila is Weltanschauung, the philosophical foundation that forms the basis of the state and ideology of the Indonesian state. The provision was born from the various values contained in the five Pancasila precepts and was later concretized in the state's goals as stated in the Fourth Paragraph of the Opening of the Constitution of the Unitary State of the Republic of Indonesia in 1945 The Fourth

16 Sentanoe Kertonegoro, Social Security and Implementation in Indonesia. The second printing. Mutiara Sumber Widya, Jakarta, 1987,page. 7

17 Edi Suharto, Building a Community Empowering People: Strategic Study of Social Welfare Development and Social Work, Refika Aditama, Bandung, 2005, page. 26.

18 Siswono Yudo Husodo, Pancasila: The Road to a Prosperous State, in Proceedings of the Symposium and
Paragraph of the Opening of the 1945 Constitution of the Unitary State of the Republic of Indonesia ${ }^{18}$. Article 33 Paragraphs (1) and (4) of the 1945 Constitution of the Republic of Indonesia state that "The economy shall be arranged as a joint effort based on the principle of kinship. The national economy is organized based on economic democracy with the principles of togetherness, fair efficiency, sustainable, environmentally friendly, independent, and by maintaining a balance of progress and national economic unity. Article 33 of the 1945 Constitution states that natural resources are controlled by the state and are used maximally for the prosperity of the people. So that the monopoly of the arrangement, administration, use, supply, and maintenance of natural resources and the regulation of legal relations lies with the state. Article 33 explains that the Indonesian economy will be supported by 3 main actors, namely Cooperatives, State/Regional-Owned Enterprises, and Private which will realize economic democracy characterized by market mechanisms, as well as government intervention, and recognition of property rights individual. ${ }^{19}$

Cooperatives are the cornerstone of the Indonesian economy. The meaning of the pillar of the teacher is a "pillar" or "pole". The term cooperative as a pillar of the economy can be interpreted that the cooperative as a "pillar" or "main buffer" or "backbone" of the economy, its existence is expected to be a pillar of the community because it is social, avoiding the individualistic nature / fertilizing profits for the person but even so the cooperative also does not rule out individual rights, he is also in harmony with the nation's culture of mutual cooperation and help please. To activate the

Workshop, Monday-Tuesday, August 14-15, 2006, Pancasila as the National Science and Development Paradigm, published by the collaboration of Gajah Mada University, Indonesian Institute of Sciences and the Institute for Resilience National, Yogyakarta, 2006, page.5.

19 Article 33 Paragraphs (1) and (4) of the 1945 Constitution of the Republic of Indonesia state 
Cooperative as a pillar of the economy, the Cooperative must function and be played for:

a. Build and develop the potential and economic capacity of members in particular and society in general to improve their economic and social welfare;

b. Participate actively in efforts to enhance the quality of human and community life;

c. Strengthening the people's economy as a basis for the strength and resilience of the national economy with the Cooperative as a pillar;

d. Trying to realize and develop the national economy which is a joint effort based on the principles of family and economic democracy.

e. As a government partner in order to accelerate the reduction of the level of social and economic inequality, realize social and economic justice, contribute to increasing employment opportunities, and promoting sustainable development.

Cooperatives have something in common with the original Indonesian social system, collectivism. The Indonesian community members love to help. While cooperatives also adhere to the principle of please help. Cooperatives can also educate tolerance and a sense of shared responsibility. Thus, said Bung Hatta, cooperatives could educate and strengthen democracy as the ideals of the nation. Furthermore, Bung Hatta said, the cooperative will also educate the spirit of believing in one's own strength. At the very least, this spirit of "self help" is needed to eradicate the disease of "inferiority complex" inherited from colonialism.

The conception of cooperatives is in line with the principles of economic life of the Indonesian people. Economic principles that prioritize kinship and cooperation, as well as economic democracy which then with populist economy. Democracy economics is the Indonesian National Economic System based on kinship, popular sovereignty, morality of Pancasila, and shows serious concern for the people's economy. Indonesia is more applied to stay away from the application of capitalist economy and is more likely to approach the populist economy (institutional). This is based on the fact that popular economics (institutional) is far more capable of analyzing the problems faced by Indonesian cooperatives.

The ideal construction of public policy the role of cooperative business entities in the field of construction services in realizing public welfare based on the value of justice. The ideal construction value of the cooperative public policy in the field of construction services in realizing community welfare based on the values of justice is the public policy regarding cooperative business entities in the field of construction services that form cooperatives as construction business entities that can grow and develop. at the State-Owned Enterprises level. Cooperative business entities in the field of construction services will advance the welfare of members, namely experts and workers. This business entity system will help the government advance the welfare of the community and build a national economic order to create an advanced, just and prosperous society based on Pancasila and the 1945 Constitution. By reconstructing the legal norms in the provisions of Article 6, Article 15, and Article 16 of Law Number 25 the Year 1992 concerning Cooperatives. The formation of cooperatives as regulated in Article 6 of the Cooperative Law, it is necessary to regulate Cooperatives in the Field of Secondary Cooperative Construction Services formed at least 15 (fifteen) Business Entities. Furthermore, in Article 15 and Article 16 of the Cooperative Law, it is necessary to regulate the form and type of cooperatives. Cooperatives can be in the form of Primary / Secondary Cooperatives and or Construction Services Cooperatives. The type of cooperative is based on the similarity of activities, economic interests, and or construction services and the economic interests of its members in realizing the welfare of the community.

\section{Conclusion}

Factors that influence cooperative public policy that has not been able to play a role in the field of 
government construction services by basing on legal system theory are caused by 3 legal subsystem factors (first legal factors, second legal structure factors, and legal culture factors). Legal factors, namely Law Number 25 of 1992 about Cooperatives have not explicitly governed the form and type of cooperatives in the field of construction services. The structural factor is that there are no government alignments regarding the regulation of construction services and the profitability of business entities does not favor workers/employees. Business entities outside the cooperative business entity have not been able to assist the government in realizing the welfare of the community. Furthermore, in terms of legal culture, the capital of government construction services still relies on outsiders, namely investors, and covers the economic system of capitalism. The ideal construction value of the cooperative public policy in the field of construction services in realizing community welfare based on the values of justice is the public policy regarding cooperative business entities in the field of construction services that form cooperatives as construction business entities that can grow and develop. at the State-Owned Enterprises level. Cooperative business entities in the field of construction services will advance the welfare of members, namely experts and workers. This business entity system will help the government advance the welfare of the community and build a national economic order to create an advanced, just and prosperous society based on Pancasila and the 1945 Constitution. By reconstructing the legal norms in the provisions of Article 6, Article 15, and Article 16 of Law Number 25 the Year 1992 concerning Cooperatives.

\section{REFERENCES}

[1] Camelia Fanny Sitepu, Hasyim, Perkembangan Ekonomi Koperasi di Indonesia, Jurnal Niagawan, Vol 7 No 2 July 2018.
[2] Caroline Gijselinckx Patrick Develtere, The Co-operative Trilemma. Co-operatives between market, state and civil society, Paper presented at the 8th Conference of the European Sociological Association on 'Conflict, Citizenship and Civil Society', sessions of the Economic Sociology Research Network, Glasgow, 3-7 september 2007.

[3] Aji Basuki Rohmat, Analisis Penerapan Prinsip-Prinsip Koperasi Dalam UndangUndang Koperasi (Study of Law No. 25 Tahun 1992 and Law No.17 Tahun 2012), Jurnal Pembaharuan Hukum, Volume II No. 1 January - April 2015.

[4] Revrisond Baswir, Peran Koperasi Dalam Mewujudkan Perekonomian Yang Berkeadilan Sosial, Economic Journal of Emerging Markets (EJEM) Vol 2, No 2. 1997.

[5] Elfa Murdiana, Analisis Yuridis Sosiologis Terhadap Perubahan Undang-Undang Koperasi, e-journal STAIN Jurai Siwo Metro.

[6] Lathifah Hanim, Perlindungan Hukum Bagi Para Pihak Dalam E-Commerce Sebagai Akibat Dari Globalisasi Ekonomi, Jurnal Pembaharuan Hukum, Vol.I No. 2 May-August 2014.

[7] I Made Asu Dana Yoga Arta, Status Kepemilikan Badan Usaha Milik Negara (Bumn) Persero Setelah Dikuasai Oleh Pihak Swasta, Jurnal IUS, Vol.V No.2 August 2017.

[8] Warno, Kepatuhan Koperasi Dikota Semarang Dalam Membuat Laporan Promosi Ekonomi, Journal of STIE Semarang, Vol.4 No.2 June 2012.

[9] Josefhin Mareta, Constitutional Economic Principles in the Privatization of State Owned Enterprises: Constitutional Journal, Volume 15, Number 1, March 2018. 
[10] Djauhari, Politik Hukum Negara kesejahteraan Indonesia, Unissula Press,Disertasi,Semarang,2008.

[11] Satjipto Rahardjo, Legal Studies, sixth printing, Citra Aditya Bakti, Bandung, 2006.

[12] Sudikno Mertokusumo, Know the Law: An Introduction, Fourth printing, Liberty, Yogyakarta, 2008.

[13] Lawrence M.Friedman, American Law, WW Norton \& Company, New York, 1984.

[14] Mubyarto, Ekonomi Pancasila, Gagasan dan Kemungkinannya. PT. Pustaka LP3ES Indonesia. Jakarta, 2007

[15] Gianfranco Poggi, The Development of the Modern State "Sosiological Introduction, Standford University Press, California, 1992.

[16] Sentanoe Kertonegoro, Social Security and Implementation in Indonesia. The second printing. Mutiara Sumber Widya, Jakarta, 1987.

[17] Siswono Yudo Husodo, Pancasila: The Road to a Prosperous State, in Proceedings of the Symposium and Workshop, MondayTuesday, August 14-15, 2006, Pancasila as the National Science and Development Paradigm, published by the collaboration of Gajah Mada University, Indonesian Institute of Sciences and the Institute for Resilience National, Yogyakarta, 2006.

[18] Edi Suharto, Building a Community Empowering People: Strategic Study of Social Welfare Development and Social Work, Refika Aditama, Bandung, 2005.

[19] Law No. 25 of 1992 Concerning Cooperatives

[20] The 1945 Constitution of the Republic of Indonesia

[21] Hanim, L. (2014). Perlindungan Hukum Bagi Para Pihak Dalam E-Commerce Sebagai Akibat Dari Globalisasi Ekonomi. Jurnal Pembaharuan Hukum, 1(2), 191199.
[22] Murdiana, E. (2015). Analisis Yuridis Sosiologis Terhadap Perubahan UndangUndang Koperasi. Istinbath: Jurnal Hukum, 12(1), 133-152.

[23] Suharto, E. (2005). Building Communities Empowering People. Bandung (Id): Refika Aditama. 